\section{Theories and Practices of Development: An Anthropological Perspective}

\section{Binod Pokharel}

\section{Abstract}

Development is a contested ideology and concept. There is a long anthropological tradition that looks at development actions and events from different perspectives. Each perspective has its own explanation, methodology, epistemology, interest articulation, imagination and policy agenda. It seems that development policy and practice has been periodically regenerated and reformulated with new ideas and thinking. In recent years, anthropologists have increasingly been involved in the ethnographic study of development projects, such as strategies, policies, practices and organizations. Despite the growing number of development literatures in Nepal, few studies have examined interfaces between development projects and local politics. Broadly, there are two traditions of looking at the community development in Nepal. The first category of literature is basically concerned with social transformations through development intervention. The second type is more interpretive and focuses on discourse analysis.

Keywords: Development, modernization, post-modernization, discourse, participatory approach, policy, practice, strategy

\footnotetext{
${ }^{1}$ This article is a revised version of a chapter of $\mathrm{PhD}$ dissertation which was submitted to Tribhuvan University in 2010.
}

\section{Introduction}

This article briefly reviews different dimensions of development from multiple perspectives and assesses the major community development policies and programs that have been conducted in Nepal and elsewhere. The aim of this article is to show how development policies and strategies have been shifted in different time and space. The first part of article briefly highlights development debate from different perspectives. The second part is concerned on policy, approaches and practices of participatory and community development. Finally, this article locates the policy and practices of development in the Nepalese context.

\section{Theoretical and Conceptual Debate}

There is a long anthropological tradition that looks at development actions and events from different perspectives. Each perspective has its own explanation, methodology, epistemology, interest articulation, imagination and policy agenda. Methodologically and epistemologically, we can broadly divide anthropological perspectives into different categories: modernization theory, including classical structuralism and functionalism, Marxist theory, including neoMarxist and political economic approach, and finally postmodernist and post-structuralist thinking on change and development. In recent years, many anthropologists have observed development from postcolonial, subaltern and indigenist perspectives. It is seen that development theories are treated as ideologies which set agendas, frame priorities, build coalitions and justify policies. Development, in both theory and practice, according to Gardner and Lewis, is essentially a polarized series of events and actions that are in some way associated with one or another political discourse and ideological construct (1996, p. 25). It is argued that "each approach has its own trajectory and contextual specificities, and is characterized by particular debates and empirical experiences” (Hickey and Mohan, 2004, p. 5). It seems that development policy and practice has been 
periodically regenerated and reformulated with new ideas and thinking.

The mainstream theories such as Modernization and Marxism analyze macro-level issues of development. Traditionally, the modernization paradigm explains development as a process and underdevelopment is described as an obstacle for development. Profitmotivation, economic rationality, improvement of infrastructure, information technology and the training of local personnel and bureaucrats, investment of foreign capital and secularism are some of the major development policies and practices of modernization theory. In addition, differentiation and social mobilization are core concepts for rural and community development. Differentiation means the separation of the political sphere from the religious sphere. Social mobilization refers to the process by which traditional social and psychological loyalties are broken down so that new arrangements of society and economy may be possible (Lewellen, 1983, p. 118). The benefit of development is achieved through the trickle down approach. Now traditional thinking of modernization has changed in several ways. It emphasizes the role of macro-structures towards more agency-oriented views. The process of modernization facilitates the transition from one historical period to the other. This process of modernization is directed by national elites through policy initiatives and the paradigm is considered a celebration of western civilization` (Hulme and Turner, 1990, p. 35).

Marxist theory, including its sub-variants, uses capitalism as its primary focus of attention in seeking to analyze the way the modern world economy evolved and is currently constituted. They most often empirically examine the development processes that affect people. For Marxist anthropologists, capitalism and modernization are two parts of the same coin. Marx assumed that the capitalist has access to power because of their position in the economic structure; they own the means of production... the political arrangements consolidate the economic ones (Smelser 1988, pp. 7-8). They believe that development is led by decolonization and modernization. Decolonization and modernization, according to Mishra (2005, p. 96), were simultaneously liberating and imperializing Third World Countries. Marxist analyses as a whole accept the desirability of development, but they ignore the micro level transformations and give priority to larger social and political structures for micro-level social transformations that occur (Frank, 1971; Amin, 1976). They analyze and confront structures of operation within existing forms of economic development, state formation, political rule and social differentiation (Hickey and Mohan, 2004). For them, participatory citizenship is a means of challenging subordination and marginalization processes created by capitalistic expansion. Marxist development policy is straightforward and is concerned with equitable distribution and the efficient allocation of resources. They believe in primacy of the state in development where the state manages development problems through the strategic action of the working population in the ever-changing balance of class force.

Foucault is concerned with power, and the relationship among the power, knowledge and discourses. Panopticism, according to him, is one of the characteristic traits of our society. It's a type of power that is applied to individuals in the form of continuous individual supervision, in the form of control, punishment and compensation, and in the form of correction, that is, the molding and transformation of individuals in terms of certain norms. This threefold aspect of panopticism-supervision, control, correction-seems to be a fundamental and characteristic dimension of the power relations that exist in our society (Michel- Foucault.com 2009).

For him, knowledge and power an agent of transformation of human life (1984, p. 17). The growth and spread of disciplinary mechanisms of knowledge and power preceded the growth of capitalism in both the logical and temporal sense. However, Foucault is not concerned with the growth of capitalism. His concern is the subject and power, as well as the political rationality which has bound together (1984, p. 18). Foucault discusses on how power is enjoyed by government over its subjects.

Escobar (1995) and Ferguson (1994) provide new insight in understanding the development phenomena. Like Foucault, they 
devote far greater attention to rhetorical and discursive strategies, like the interplay of ideas, myths, and language in defining worldview, that were critical in the creation of the concept of development. In the past development, according to their observation, is a system of power that regulates its subjective practices and forms by discourse, through which people come to recognize themselves as developed or underdeveloped. For Ferguson, development is an apparatus that forms power and intervention, which results in the mapping and production of Third World Societies (Ferguson, 1994).

Escobar has made major contributions to the anthropology of development. He has closely analyzed contemporary development processes and practices in the world. He shows how development in the Western model dictated the marginalization and disqualification of non-western knowledge systems of development (1995, p. 13). His work focuses on the regimes of representation that underlie constructions of peasants, women, and the environment. He also contributes to theorizing question of discursive change and transformation by explaining how the discourse of peasants, women, and the environment emerges and functions in similar ways within the overall space of development. For him development is a historically produced discourse.

He also criticized the role of anthropologists stating that they overlook the ways in which development operates as an arena of cultural contestation and identity construction (p. 15). He suggests the needed liberation of anthropology from the space mapped by modernity, to be achieved through a close examination of the ways in which it has been implicated in it, is an important step in the direction of more autonomous regimes of representation. This is in order to motivate anthropologists and others to delve into the strategies people in the Third World to pursue, resignify and transform their realities through their collective political practice. This challenge may provide paths toward the radicalization of the discipline's reimagining; starting with the enthusiasm it generated during the 1980s (p. 17). Finally, Escobar focuses on the radical critique of Western historical and epistemological dominance in the regime of development in third world countries including Nepal.

Ferguson sees development as an apparatus and focuses on the expansion and entrenchment of government power. He mentions that development is inherently problematic and some aspects of development are actively destructive and disempowering (Ferguson, 1996, p. 25).

Like Foucault, Ferguson (1994) is also concerned with the international development apparatus and sees "development as problematic or interpretive grid through which the impoverished regions of the world are known to us" (1994, p. xiii). He argues that even the failed development project can bring about important structural changes (1994, p. 275). Development, according to him, is a machine for reinforcing and expanding the exercise of bureaucratic state power, which incidentally takes poverty as its point of entry (1994, pp. 255-56). The instrumental effect of development project, according to Ferguson, is twofold. Alongside the institutional effect of expanding bureaucratic state power, is the conceptual or ideological effect of de-politicizing both poverty and the state (1994, p. 126). Development interventions are organized on the basis of knowledge structures. The expansion and entrenchment of bureaucratic state power and the projection of representations of economic and social life deny politics and, to the extent that it is successful, suspends its effects (pp. xiv-xv).

Some of the scholars (Fujikura, 2004; Fisher, 1997; Arellanno and Petras, 1994; Shah 2004) question the applicability of Ferguson's findings in the present context of Nepal and elsewhere. They challenge Ferguson's conclusion and state that Ferguson's case is based on his critical observations of an integrated rural development program `in Lesotho from the late 1970s to the mid-1980s. The operation of development has changed significantly since then. Fujikura (2004) demonstrates that the most significant changes have been the proliferation of NGOs over the course of the 1990s and the emergence and growth of complex networks of ideas, funding and people that have accompanied it. Shah (2004) views that the 
unintended consequences need not necessarily have a depoliticizing effect as Ferguson records in Lesotho. His findings suggest that local actors can very appropriate the apolitical economic intervention to press on political agenda.

\section{Policies and Practices of Community Development}

In recent years, anthropologists have increasingly been involved in the ethnographic study of development projects, such as strategies, policies, practices and organizations (Shore and Wright 1997; Mascarenhas, 2001; Mosse, 2001; Hirsch and Gellner, 2001). They are little concerned with the successes and failures of the development project and instead focus on the social manufacturing of success or failure. The Development project comprises of multiple actors and stakeholders. It is also a political system where different perspectives contend for influence and authority: "It involves not only project staff and participating villagers, but also donors, consultants, bureaucrats, senior agency managers, and local government representatives, among others” (Mosse 2001a, p. 160). Development practices, according to Mosse (2001b), involve the constant negotiation, advocacy, and strategic deployment of information as much as its production through research. There is often a gulf between stated policy and the actions the organization actually takes. This difference is sometimes caused by political compromise over policy, while in other situations it is caused by lack of policy implementation and enforcement. Implementing policy may have unexpected results, stemming from a policy whose reach extends further than the problem it was originally crafted to address. Additionally, unpredictable results may arise from selective or idiosyncratic enforcement of policy (See Burghart 1993; Foster 1962).

David Mosse (2005) outlines the new ethnography of development where he offers a policy and practice of development. He presents five propositions about the relationship between policy, including all kind of development models, project designs and strategies and development practices. According to him, "development interventions are not driven by policy but by the exigencies of organizations and the need to maintain relationship" (p. 16). Unlike post-modernists, he argues that 'policy models which work well to legitimize and mobilize political support do not provide a good guide to action, nor can they easily be turned into practice` (p. 16). Projects are sites of social and institutional reproduction. Policies are ignored, resisted, consumed or tactically used in ways that make them irrelevant in the face of more urgent relational demands (p.16). According to him, development projects work to maintain themselves as coherent policy ideas, as system of representations and operational systems. He says that the logic of practice routinely contradicts policy models. Mosse (2005) states that projects do not fail; they are failed by wider network of support and validation. Success and failure, according to him, are policy-oriented judgments that obscure project effects.

Mosse's findings regarding policy are based on his persistent observation and experience while he was working in the British Aid community development project in India as an insider developer. His work also clearly reveals that how development projects work in rural settings of India. Unlike traditional ethnographers, he not only observes others' activities but also shows what he did while working in the development project.

\section{Approaches of Community Development}

Classic community development projects have undergone certain transformations over the years and space. Community Development, for example, initiated in early 1950s followed by Integrated Rural Development Project and Basic Needs Approach in 1970s and early 1980s. In the beginning of the 1980s, many planners, policy makers, donor agencies and other academics realized that the past model for development could not succeed in addressing the needs of the poor population. Studies have shown that techno-economic model of development is unable to address the realities of diversity and 
complexity prevailing in Third World nations (Gardner and Lewis, 1996, p. 43).

\section{Participatory Approach}

Participatory approaches in community development have been synthesized from various thoughts, ideologies and movements and is comprised of some of development's central concepts, such as "development-centered on man, putting people first, putting the last first, development from below, grassroots-up development, culture based strategy of development, participative development, development as liberation and empowerment, small is beautiful, local is lovely, indigenous knowledge system and development" and others (Devkota, 1999, p. 75). Participatory approach had remained the dominate ideology in the field of community or rural development in late 1980s to late 1990s. Some scholars (Masaki, 2004; Fujikura, 2004) found that participatory development has stood on the side of disadvantaged groups. According to them, participatory development opened up spaces for the oppressed group of people who then became able to challenge existing social orders through development projects. The local knowledge and empowerment of local people through their involvement in development processes are overwhelmingly adopted in participatory techniques within development policy and practice (Chambers, 1983). The main objective of participatory approaches to development was to make people central to development by encouraging the beneficiary's involvement in interventions that affect them and over which they previously had limited access, control or influence (Chambers, 1983; Devkota, 1999; Cook and Kothari, 2001). Chambers (1983) provides an alternative development model for rural development by criticizing the top down model and mainstream research trends. He focuses on the rise and practice of participatory development analysis. He persistently argues that the "top-down" model of development starts with disciplinary specialization and uses its tools to examine many individuals. On the contrary, according to him, bottom-up analysis starts with the condition of the real world of the poor people, their resources, aspirations and problems.

Reversal of learning is the main focus of this approach. Chambers suggests that outsiders should first learn from farmers and from the rural poor. But many outsiders are hindered from such learning in reverse by their educational attainment, urban status, and roles as bearers and dispensers of modern knowledge (p. 201). The knowledge of any group of rural people, he claims, is accessible to outsiders only through learning from rural people themselves. The development practitioners and researchers, according to him, should understand the knowledge systems of the rural people and elicit their technical knowledge. Participatory rural appraisal aims to mobilize indigenous capacities for the self-management of development projects (p. 201). The Participatory approach creates the reverse situation for the poor.

In the post 1990s' government, I/NGOs and other grassroots organizations followed this model in villages and communities of Nepal. This approach has been used in multidimensional areas such as community forestry and health, irrigation, adult education, environment, income generation, the creation of community services, Dalit and gender issues, etc.

The development practitioner saw this approach as a technique of solving every problem of the village society. However, empirical findings show that participatory approaches produce both intended and unintended consequences in everyday social life. Cook (2001), Kothari (2001), Cleaver (2001), Mosse (2001), Hickey and Mohan (2004) largely discuss the theoretical, methodological and practical problems of the Participatory Learning/Planning Approach (PRA/PLA). They also dig out the paradox of PRA and question the participatory approach in development. They view that participatory development has often failed to engage issue of power and politics. They see participatory development as a new tyranny that depoliticizes the political issues. They outline some of the conceptual underpinnings of participatory approaches and why PRAs could not achieve their desired impact upon people.

However, local knowledge produced through participatory 
techniques is not unproblematically authentic. It is mediated and reflects project-community and intra-community power relations (Mosse, 2001a). Mosse further notes that participation as a discourse has important power effects: "for development agencies; it is an important legitimizing strategy, and thus becomes central to the presentation of project activities to audiences of powerful outsiders." He confronts the "populist assumption that attention to local knowledge through participatory learning will redefine the relationship between local communities and development organizations” (Mosse, 2001a, pp. 17-18). According to him, local knowledge is far removed from planning processes and outcomes and instead is often structured by them. Presenting project based information, he states that local need was actually shaped by local perceptions of what the agency in question could legitimately and realistically be expected to deliver. Indeed, participatory planning is to be viewed as the acquisition and manipulation of a new planning knowledge rather than the incorporation of people's knowledge by projects. Kothari (2001) challenges some of the truth made by PRA practitioners about the validity of the data collected and raise question about the extent to which it represents the local knowledge. She views that participatory methods discursively construct their clients in particular and often times problematic ways, placing responsibility for the outcomes of development projects squarely on the shoulders of their beneficiaries (pp. 164-165). Unlike Chambers claims, Mosse saw that "participatory approaches have proved compatible with top down planning systems, and not necessarily heralded changes in prevailing institutional practices of development”(2001a, p. 17).

There is no doubt that PRA events have helped construct a forum or space for the contestation and reevaluation of identity and resistance. However, neither shapes actual practices in the way that they claim, nor does local knowledge provide a radical challenge to existing power structures, professional positions and knowledge systems (Mosse 2005, p. 16).

\section{Reframing Participation: Empowerment Approach}

The growing criticism of populist participation in the 1990s participatory approach has been reframed in a new direction. UNDP adopted the empowerment approach that stresses enhancing individual's entitlements, capabilities, rights and freedom. These are the four pillars of human development which reinforce the other three: equity, productivity and sustainability aspects (UNDP, 2004, p. 2). Unlike the previous approach, it gave equal importance to economic, socio-cultural and political dimensions of empowerment. After the declaration of millennium goal in 2000, right and entitlement agendas have been widely reflected in development agencies' (UNDP, World Bank, IMF DFID, etc) discourse. Millennium Development Goals (MDGs) were approved by the General Assembly of the United Nations in 2000. Empowerment approaches and poverty reduction became common objectives for international development agencies. The World Bank and International Monetary Fund adopted Participatory Poverty Reduction Strategies (PRSPs) to achieve the Millennium Development Goals. The World Bank, including other donor agencies, has identified socio-cultural empowerment as one of the key constituent elements of poverty reduction, and as a primary development assistance goal (Malhotra et al., 2002, p. 3). According to Holland, Brocklesby and Abugre, "Poverty reduction during the early part of the 1990s was driven by a slavish adherence to the poverty line, with insufficient emphasis on identifying the underlying dimension of poverty in any particular society or context” (2004, p. 252).

This approach incorporates issues like citizenship rights, governance, political space, political capabilities, political contract and political capital to address the critiques of the participatory approach: "it emphasizes that participation needs to be practiced in the broader spaces of the political community beyond the project level, and recognizes the need to reconnect the populist methods of participation with more politicized understandings of social change" (Hickey and Mohan, 2004, p. 169). All these efforts are concerned 
with making participatory development more transformative with a focus on human rights and social justice. This approach also rejects "participation" in its current form and seeks radical alternatives in relation to "alternative development thinking" (p. 12).

There is growing focus by NGOs on right-based approaches to development, and they have become increasingly involved in the field of advocacy, social movements and participatory development. Recently they broadened their agenda towards institutional issues of governance as well development policy and practices. Similarly, they are engaged with wider debates concerning the changing state in relation to processes of democratization and decentralization. Methodologically, they are little bit away from the populist participatory approaches. In some cases, they sharpen up conventional PRA techniques with the REFLECT approach which was initially developed by Action Aid.

It is obvious that NGOs have transformed the way in which they engage with marginal groups by relating to them as agents with claims rather than as victims in need of rescue and rehabilitation (cited in Hickey and Mohan, 2004, p. 164). NGO advocacy involves the alignment of participatory approaches with the rights-based agendas and brings together the key elements of citizenship-based approaches which stresses political engagement at local, national and international levels (p. 165).

The new paradigm of participatory approaches is the convergence of different perspectives and ideologies that includes issues of politics, citizenships, human rights and advocacy in development arenas. Interestingly, unlike previous development approaches and policies, the major development agencies adopted common objectives and approaches to achieve the millennium goal of development. Below is a discussion on the policy agenda (political space for the poor, social mobilization and social capital approach) adopted by the UN to achieve the millennium development goals.

\section{Political Space for Poverty Alleviation}

When the millennium development goals were declared poverty became a political issue. Rights based approaches for poverty alleviation and development assert the need of political space for the poor people through local organizations. It is a political methodology of empowerment. Rights-based development attaches political rights and responsibilities to fundamental aspects of human needs and wellbeing (UNDP, 2000 cited in Hickey and Mohan, 2004, p. 163). Strengthening local organizational capacity-building and social capital, especially through social mobilization, plays a vital role in enhancing the productivity of assets available to poor by protecting the fulfillment of their basic needs and managing risks and conflict (UNDP, 2004, p. 15). Policy makers and practitioners have become increasingly involved in community organizations, decentralized governments, local offices of ministries and NGOs in order to address the issues of poverty (Engberg-Pederson and Webster, 2002, p. 4). Below issues of social mobilization and social capital are reviewed. They are considered major vehicle of this century for community development and the reduction of poverty.

\section{Social Mobilization through Local Organizations}

In the 1950s and 1960s, social mobilization was taken as the means of social transformation under the modernization paradigm (Deutsch, 1961). This approach of community development has been reframed over the years. Mobilization is a process through which community members become aware of a problem, identify the problem as a high priority for community action, and decide steps to take action (Thompson and Pertschuk, 1992). It starts with problem assessment and analysis at the community level and moves to take action on chosen courses, involving many strategic allies at all levels in a wide range of support activities. Central to social mobilization interventions is empowerment or the process through which individuals or communities take direct control over their lives and environment 
(Minkler, 1990). Now mobilization becomes as a strategy to achieve the millennium goal of development. Development practitioners believe that decentralization and democracy can be pursued at the local level through grassroots organizations and community-based groups. UNDP states that local organizations unfold the political space for poor and marginalized groups of people where they can claim their rights and responsibilities.

Social mobilization has become the cornerstone of participatory approaches and poverty alleviation programs. Development agencies have recognized that there should be organizations formed by the poor's own initiatives in order "to secure their interests by effecting change in the actions and policies of others and, in particular, bringing about change in public policy and in its implementation" (Engberg-Pedersen and Webster, 2002, p. 7). UN policy provides a framework to ensure that the interests of poor people form a part of development projects and that equal opportunity is accorded to these groups that markedly separated from dominant groups in a country. Local organizations have been taken as an instrument for institutional capacity building at the local level. Because local organizations are less controversial, locally based, familiar and acceptable to local people, they provide avenues for the introduction of Euro-American Experiences in local languages and development discourses (Blunt and Warren, 1995, p. xv).

Studies (Harmmar, 2002; Rajasekhar, 2002; Masaki, 2004; Westergaard and Hossain, 2002; Engberg-Pedersen and Webster, 2002) show that government policies, programs, project interventions and local level organizations produced space for political contestation. Hammer displays how states in Zimbabwe have engaged in space ordering practices that have been aimed simultaneously at territorial control and asserting political authority (2002, p. 129). Her study shows that Mugabe's government and other different actors strategically used the new land policy to promote their particular interests.

Masaki made the case that development found that tyrannical attributes inherent in people's participation co-exist with transformative forces (2004, p. 126). He demonstrates that not only dominant groups and political parties succeed in making space for political change and development projects but marginalize groups also use the new space for their benefits. The study shows that the transition to the multi-party system in 1990 opened up political opportunities to contest power for Tharus in Western Nepal, who increasingly express their discontent with the corveé a long tradition that has long served as the backbone of the Pahadi dominance (p. 117). Westergaard and Hossain reveal the mixed picture of NGO involvement in space making process in rural Bangladesh. They show that clientelist relations of domination were weakened following the exploitation of the political space by advocacy NGOs and the emergent political agency of mobilized groups of poor. However, on the other hand, either the poor did not exploit the emerging political space, their elected representatives were quickly absorbed by the clientelistic relations, or they were confronted by strong and sometimes violent action by political elites whenever they succeeded in obtaining a firmer hold on seats in local government (2004).

Water User Committees (WUC) and other types of community organizations in Nepal emerged as "potent arenas for political contestation” (Sharma 2004). Sharma observed that WUCs became new arenas for gauging one's political strength. Because of its association with bikas, the supposedly neutral WUC increasingly saw political battles fought during its elections (p. 107). He notes that WUC developed as forum where local people saw the project as opening up new social spaces: "It provided opportunities to some who were opposed to the VDC chairman to move into positions of leadership themselves" (p. 107). His study also demonstrates that educated and articulate persons who had imbibed the ideology of bikas were coming into leadership positions in these forums. It is seen that in some cases community organizations or user groups in Nepal are clearly being used to "legitimate the interest of some" (Shah, 2006, p. 6). 


\section{Social Capital}

Social capital refers to connections within and between social networks and is a core concept in community development. It is one of the components of the Empowerment Approach adopted by various development agencies. Anthropologists and others (Bourdieu, 1987; Putman, 1993; Messerschmidt, 1978; Uphoff, 1996; Ramble, 1984; Ostrom, 1990 1992; Chhetri, 1995; Rankin, 2002; Upreti, 2007) analyze the various forms of social capital as local level self-help associations. Rankin stresses the importance of social capital to community development and empowerment.

The mainstream development agencies adopted this strategy rapidly after 1990s by restructuring previously nationalized banking systems and devolving rural credit delivery to new set of financial institutions specializing in banking with poor (Rankin, 2002, p. 11). It is seen that the underlying philosophy of social capital is to introduce the ideology of neo-liberal economy in the interior part of the world.

The special feature of the social capital, like trust, norms, and networks, is that it is ordinarily a public good, unlike conventional capital, which is ordinarily a private good (Putnam, 1993, p. 170). The mainstream development agencies (i.e. World Bank) defined and constructed social capital within the liberal tradition as cultural properties, the norms and networks that enhance efficiency by facilitating co-operation (Rankin, 2002, p. 2). Putnam views that social trust is an essential component of social capital that can arise from related sources - norms of reciprocity and networks of civic engagement ( pp. 170-71).

Bourdieu defines social capital as "the aggregate of the actual or potential resources which are linked to possession of a durable network of more or less institutionalised relationships of mutual acquaintance and recognition." His treatment of the concept is instrumental, focusing on the advantages to possessors of social capital and the "deliberate construction of sociability for the purpose of creating this resource (1987).
Unlike other scholars, Uphoff (1996) talks about cognitive or normative aspect of social capital. He discusses the inextricability of the objective and subjective realms. He demonstrates the penchant for avoiding the propensities of social scientists who regard personal values as epiphenomenal as aberrations. He avoids reductionism as a dominating mode of thought in social science shaped by Newtonian concepts of mechanistic cause and effect. He adds that the postNewtonian social science looks beyond reductionist thinking to tap the social energy to be found in collective action and non-material realities.

As far as Nepalese case is concerned, the social capital model is a contestable and debatable issue. An ethnographic study done by Rankin (2002) among the Newar community of Kathmandu demonstrates that development interventions seeking to indiscriminately promote social capital risk entrenching the hegemony of dominant interests. She views that the members of social capital are positioned and experienced associational life differently. Some people benefit at the expense of others.

Upreti (2007) analyzes and discusses the role of panoply of cognitive or normative social capitals for managing water for irrigation as a common property resource in a western Tarai village of Nepal. His findings show that society is a moral order and normative prescriptions operate at every level of society. These prescriptions have implications for social control because they work as positive or negative means of ensuring conformity in the society's or community's rules of resource management. Those who do not conform are sanctioned for deviant behaviour (p. 215). For Upreti, friendship, leadership, trust and attitudes are aspects of strong cognitive/normative social capital that have the potential to contribute to the efficiency of the irrigation system. There is no doubt the importance of cognitive aspects in the operation of irrigation management. However, Upreti did not discuss the structural capital that has effects over cognitive or normative aspects of social life. All type of social organizations, including irrigation management hierarchies and power politics play important roles in the operation of 
irrigation canals. Some people enjoy more power and resources than others because they are embedded within larger political parties and socio-economic positions in the society.

\section{Locating Policy and Practices in Nepali Context}

Concerning the Nepalese materials on community development, a wide range of issues of policies and practices are covered. These literatures have made substantial contribution to understand the policies and practices of community development and social transformation in Nepal. Literatures show that development events produce space for interaction, contestation and grievances.

\section{Ethnographic Studies of Process and Consequences of Development}

Justice (1986), Pigg (1992, 1993, and 1999) and Harper and Tarnowski (2002) analyze the policies and practices of community health programs in Nepal from an ethnographic perspective. Justice presents how rural health policy and plan are influenced by foreign aid and examines the cultural dimension of primary health care in Nepal. She shows that the international agencies, on the strength of their economic resources, have dominated health policy and practices in Nepal and elsewhere in Third World since World War II (1986, p. 48). Both multilateral and bilateral agencies have been involved in this sector. It is seen that policy guidelines and programmatic influences come along with the foreign funds. She found that many features of the program were unsuitable for the local conditions and culture. Beyond that she analyzes bureaucratic culture and people's participation in the health sector and how they dig out the barriers to implement health policies in the rural areas of Nepal.

Unlike Justice, Pigg analyzes ideas, myths, and language associated with community health policy and practices. She addresses the cultural impact of national ideologies on development with a focus on constructions of modernity and tradition through ideas about medicine. Both policy and implementation include local traditions under the universalistic rationality of the development model (Pigg, 1999). She says that the training programs were designed to transfer the medical knowledge through the local channel. The aim of the training programs was to enhance the Traditional Medical Practitioners' (TBAs) and Traditional Medical Practitioners' (TMPs) knowledge about health practices by improving health service delivery through cooperation with existing indigenous system without replacing other medical practices. She finds, however, this scheme not only distorts local practices out of recognition but virtually ensures that local ideas are silenced and shut out of development (1999, p. 23).

Harper (2002) demonstrates several resistances to implementing the DOT (Direct Observation of Therapy) program in the central and peripheral sites of Nepal. The author notes that DOT strategy makes economic sense: "treating $\mathrm{TB}$ is the most humane thing to do in times of limited funding; treatment of TB with funding; treatment of people with TB leads to the elimination of poverty" (p. 56). According to him, DOTS, as a strategy, has allowed the tuberculosis discourse to be inserted into other on-going processes. As a result, social mobilization becomes crucial, and the health worker's task becomes one of being able to persuade politicians, the media, NGOs, business, local groups and others that DOTS is the best thing to do (pp. 56-57).

Studies done in Nepal show that the participatory approach constructs the new types of power relations amongst local communities and demonstrates how stakeholders resist the development programs in practice. It is repeatedly claimed that community forestry is a very successful project in Nepal and it is a model project for sustainability. However, empirical evidences show that the space created by community forest is used to maintain the existing power relation at local level. For example, Tarnowski (2002) reveals the socio-political dynamics of the community forestry programme in Nepal: "Community forestry decentralizing control, [and] forest resources and the rural population are subject to an 
expanding apparatus of governmental control” (p. 293). He provides us with adequate conceptual grounds to take into account the emerging power relations in the field of community forestry in Nepal. His findings suggest that community forestry provides a venue with which local elites can gain political power and experience with which they can then use to acquire political positions. According to him, there is a strong connection between political office holders and membership on FUG committees (p. 293). He also focuses on local level conspiracy in the selection processes of FUG chairman and other executive members.

Devkota (1999) reviewed different models and strategies of development in Nepal. He presented success and failure cases of development projects in rural villages of Surkhet district. He presents several cases of intervention and resistance of development strategies in Nepal. People's self-initiated efforts at a micro-level, he says, possess great potential to bring about sustainable development in rural communities. Devkota (1999) demonstrates that due to "coercive steps taken by government and non-government organizations, many village based institutions of the people such as joint family, parma, gaon sallah, pani pale, gaonle kulo samiti, gaonle ban samiti are gradually broken down. The indigenous institutions felt seriously threatened due to the imposition of new government institutions from outside (p. 515).

Undoubtedly, Devkota made a significant contribution to the study of ethnography of development projects. However, his thesis about the ideological, political and institutional aspects of development remains unanswered and he does not clearly say how certain sections of the communities get more privileges while others are marginalized from the development efforts.

\section{Discourse on Development Studies}

There are different accounts of development discourse in Nepal. The section below reviews some discourses and perspectives of Pigg, Fujikura, Ahearn, Shrestha and Bista. Pigg (1992), Fujikura (2004) and Ahearn (2004), who use texts, senses, images, language-derived models, utterances and archival material to understand the change and development of the particular community in Nepal. Bista and Shrestha demonstrate the problem of nation building. Pigg (1992) focuses on how social categories are invented through place. Development discourse, she mentions, provides an authoritative social map for Nepalese national society (p. 492). It also constructs generic and cosmopolitan villagers.

Like Escobar (1988), Pigg believes that the authority of development describes societies, names problems, and proposes solutions that comes from the aura of truth that development creates. She considers "the apparatus of bikas (the burgeoning of office jobs, the money brought in by foreign aid, the position of influence in the bureaucracy) is the source of power, wealth, and upward social mobility." Since bikas is a powerful apparatus, people would like to be a salaried staff of development implementer than receive the tangible advantage of bikas (1992, p. 511). The ideology of modernization in Nepal, according to her, is not simply a matter of western influence, but a matter of simultaneous "nepalization" and globalization ( p. 512).

On the opposing side, there are those such as Fujikura (2004) who presents an alternative discourse to understanding the past efforts development has had in Nepal. He argues that "freedom, democracy and political participation have indeed exercised constitutive forces in the discourses and practices of development from its very beginning” (2004, pp. 108-9). He contends that "development generally as involving both efforts to change the ways oneself lives in and engages with the world, on the one hand, and efforts to enable others to live in different ways, on the other” (p. 13). Like Foucault, Ferguson and Escobar, he also considers that "development is inseparably tied to the question of the power: power over self, and power over others" (p.13). Fujikura considers how the pedagogy of intervention helps raise the awareness of the people.

Ahearn (2004) observes social transformation in Nepal through the policy and practice of pedagogy. In her ethnography, she 
investigates how villagers have applied their literacy skills to the new courtship practice of love letter writing in Junigau of Palpa district. She discusses the implication of the emergence of love letter correspondences for social relations in Nepal and trace out the broader ramifications for conceptions of agency, literacy, gender, love, and social change. Of course, pedagogy intervention really helped the transformation of Nepalese society. However, we cannot see Junigaun simply as a place but must look to the larger social and economic transformations experienced by the people of Junigaun in a wider perspective of rural transformation.

Shrestha's (1998) study is based on a narrative of development victims and demonstrated how the culture of imperialism is transfused in Nepal. He argues that the victimization of development is not only limited to "the poor and downtrodden; it encompasses a wide spectrum of people in society: rich and poor, peasants and prostitute, dope dealers and development agents" (pp. x$\mathrm{xx})$. His main thesis is that we become poor and downtrodden due to adoption of Western Development Models. For him, everything from poverty, corruption, prostitution, and deepening disparity and antagonism between classes is a symptom of cultural and spiritual deterioration of Nepali society brought forth by development (p. 59). However, empirical findings (e.g. Fujikura) contest with Shrestha findings, Fujikura points out that development is not only nation building but it is a desire of individual improvement and awareness. The proliferating discourses about awareness and consciousness in contemporary Nepal, according to Fujikura, are implicated in the changing possibilities of being and acting brought forth by the often disjunctive and contradictory effects of the projects of modernization (2004, p. 331).

Bista (1991) sought to find out the causes of underdevelopment in Nepal by focusing his attention on cultural dimensions of development. Like Nanda Ram Shrestha, he also believes that education detaches the people from the workforce. Education also gives the opportunity for self- distinction from the uneducated and unsophisticated mass (p. 156). Bista considers the conflicting value systems prevalent in the development discourse in Nepal. However, Bista's work short falls of providing solid conceptual grounds that take into account the cases of development, change and social transformation in contemporary Nepal. He argues that Brahmanism and fatalistic attitudes are solely responsible for the underdevelopment of the country. Of course, the country could not achieve what people expected but this did not mean that whatever happened there is the reflection of fatalistic attitudes and Brahmanism.

\section{Conclusion}

Anthropological studies of community development with its policy and practices tended to lack political dimensions. Despite the growing number of development literatures in Nepal, few studies have examined interfaces between development projects and local politics. Broadly, there are two traditions of looking at the community development in Nepal. The first category of literature is basically concerned with social transformations through development intervention. The second type is more interpretive and focuses on discourse analysis. Many of them failed to see how political parties or other elite groups are involved in development projects in order to make a space at the local level. Development literatures also do not show how community development projects operate in the competitive political environment of Nepal. Most of the literature is concerned with the issues of developers and the impact upon the recipient communities, remaining silent on political issues.

\section{References}

Agarwal, B. (2001). Participatory exclusions, community forestry, and gender: An analysis for South Asia and a conceptual framework. World Development, 29, 1623-1648. 
Ahearn, L. M. (2004). Invitation to love: Literacy, Love letters, and social change in Nepal. Delhi: Adarsha Books.

Amin, S. (1996). On development for Gunder Frank. In Sing C. Chew \& Denemark (Eds.), The development of underdevelopment (pp. 57-86). New Delhi: Vistaar Publications.

Arellanno- Lopez, S. \& Petra, J. F. (1994). Non-governmental organizations and poverty alleviation in Bolivia. Development and Change, 25 (3), 555-568.

Bista, D. B. (1991). Fatalism and development: Nepal's struggle for modernization. India: Orient Longman Ltd.

Bourdieu, P. (1987). Outline of a theory of social practice. Cambridge: University Press.

Burghart, R. (1993). His lordship at the cobblers well. In Mark Hobart (ed.), An Anthropological critic of development (pp. 79-99). USA and Canada: Routledge.

Chambers, R. (1983). Rural development- Putting the last first. England: Longman Limited.

Chhetri, R. B. (1995). Rotating associations in Nepal: Dhikuri as capital, credit, saving, and investment. Human Organization, 54 (4), 449-454.

Cleaver, F. (2001). Institutions, agency and the limitation of participatory approaches to development. In B. Cooke \& U. Kothari (Eds.), Participation: The new tyranny (pp. 36-55). London and New York: Zed Books.

Cooke, B. \& Kothari, U. (2001). The case for participation as tyranny. In B. Cooke \& U. Kothari (Eds.), Participation: The new tyranny (pp. 1-15). London and New York: Zed Books.

Deutsch, K. W. (1961). The American Political Science Review, 55 (3), 493-514. JSTOR.

Devkota, P. L. (1999). "People Centered Development in Nepal: An Innovative Approach”. Unpublished Ph.D. Dissertation, University of Delhi.

Engberg-Pedersen, L. \& Webster, N. ( 2002). Introduction to political space. In N. Webster \& L. Engberg-Pedersen (Eds.), In the name of the poor: Contesting political space for poverty reduction (pp 1-29). London/New York: Zed Books.

Escobar, A. (1995). Encountering development. New Jersey: Princeton.

Ferguson, J. (1994). The Anti-politics machine: Development, depoliticization, and bureaucratic power in Lesotho. London: University of Minnesota Press, Minneapolis.

Ferguson, J. (1996). Anthropology and its evil twin: Development in the constitution of discipline. In F. Cooper \& R. Packard (Eds.), International development and the social sciences (pp.150-75). Berkeley and Los Angeles: University of California Press.

Fisher, W. F. (1997). Doing good? The politics and anti-politics of NGO practices. Annual Reviews of Anthropology, 26, 439439.

Foucault, M. (2009, January 15). Michel-Foucault.com access on 15 January, 2009.

Foulcault, M. (1984). The subject and power. In H.L. Dreyfus and P. Rabino (Eds.), Michel Foucault: Beyond structuralism and hermeneutics. Chicago: University of Chicago Press.

Frank, A. G. (1996). The underdevelopment of development. In Sing C. Chew \& R. A. Denemark (Eds.), The Underdevelopment of development (pp.17-56). New Delhi: Vistaar Publication.

Fujikura, T. (2004). "Discourses of Awareness: Development, Social Movements and Practices of Freedom in Nepal”. Unpublished Ph.D. Dissertation, Department of Anthropology, Chicago, Illinois (USA).

Gardner, K. \& Lewis, D. (1996). Anthropology, development and the post modern challenge. London Chicago: Pluto Press.

Hammer, A. J. (2002). Speaking with space: Displacements and claims in the politics of land in Zimbabwe. In N. Webster \& L. Engberg- Pederson (Eds.), In the name of the poor: Contesting political space for poverty reduction (pp. 129156). London/New York: Zed Books.

Harper, I. \& Tarnowski, C. (2002). A Heterotopia of resistance: Health, community forestry, and challenges to state 
centralization in Nepal. In D. N. Gellner (Ed.), Resistance and the state: Nepalese experiences (pp. 33-82). New Delhi: Social Science Press.

Hickey, S. \& Mohan, G. (2004). Towards participation as transformation: Critical themes and challenges. In S. Hickey \& G. Mohan (Eds.), Participation: From tyranny to transformation? Exploring new approaches to participation in development (pp. 3-24). London and New York: Zed Books.

Hirsch, E. \& Gellner, D. N. (2001). Ethnography of organizations and organization of ethnography. In D. N. Gellner \& E. Hirsch (Eds.), Inside organizations: Anthropologists at work (pp.118). Oxford and New York: Berg.

Holland, J., Brocklesby, M., \& Abugre, C. (2004). Beyond the technical fix? Participation in donor approaches to right based development. In S. Hickey and G. Mohan (Eds.). Participation: from tyranny to transformation? Exploring new approaches to participation in development (pp. 252268). London and New York: Zed Books.

Hulme, D. \& Turner, M. (1990). Sociology and developmentTheories, policies and practices. New York, London, Toronto, Sydney and Tokyo: Harvester Wheatshaf.

Justice, J. (1986). Policies, plans and people: Foreign aid and health development. Kathmandu: Mandala Publication.

Kothari, U. (2001). Power, knowledge and social control in participatory development. In B. Cooke \& U. Kothari (Eds.), Participation: The new tyranny (pp. 139-152). London and New York: Zed Books.

Masaki, K. (2004). The transformative unfolding of tyrannical participation: the corvee tradition and ongoing local politics in Western Nepal. In Samuel Hickey \& Giles Mohan (Eds.), Participation: From tyranny to transformation? Exploring new approaches to participation in development (pp.125139). London and New York: Zed Books.

Mishra, C. (2005). Sociology in Nepal: Underdevelopment amidst growth. Contribution of Nepalese Studie, 32 (1), 93-128.

Mosse, D. (2001a). People's knowledge, participation and patronage: Operations and representations in rural development. In B. Cooke and U. Kothari (Eds.), Participation: The new tyranny (pp. 16-35). New York and London: Zed Books.

Mosse, D. (2001b). Social research in rural development project. In D. Gellner and E. Hirsch (Eds.), Inside Organizations: Anthropologist at work (pp.157-182). Oxford and New York: Berg.

Mosse, D. (2005a). Global governance and the ethnography of international aid. In D. Mosse and D. Lewis (Eds.), The aid effect: Giving and governing in international development (pp.1-36). London: Pluto Press.

Mosse, D. (2005b). Cultivating development: An ethnography of aid policy and practice. London/Ann Arbor: Pluto Press.

Ostrom, E. (1990). Governiing the commons: Evolution of institutions for collective action. New York: Cambridge University Press.

Pieterse, J. N. (2001). Development theory: Deconstruction/ reconstruction, New Delhi: Vistaar Publication.

Pigg, S. L. (1992). Inventing social categories through place: Social representations and development in Nepal. Comparative Studies in Society and History, 34 (3), 491-513.

Pigg, S. L. (1999). Authority in translation: Finding, knowing, naming and training: Traditional birth attendents in Nepal. Re/productions, (1): 11-25.

Pokharel, D. \& Willet, A. B. J. (1996). History indigenous community management organization in Nepal. In P. Blunt and D. M. Warren (Eds.), Indigenous organization and development (pp. 109-112). London: Intermediate Technology Publication.

Putnam, R. (1993). Making democracy work: Civic traditions in modern Italy. Princeton, NJ: Princeton University Press.

Rajasekhar, D. (2002). Where local organizations do not work: Problems of poverty reduction in Tamil Nadu, India. In N. Webster and L. E-Pedersen (Eds.), In the name of the poor 
(pp. 183-207). London and New York: Zed Books.

Rankin, K. N. (2002). Social capital, microfinance, and the politics of development. Feminist Economics, 8 (1).

Shah, S. (2004). "A project of Memoreality: Transnational Development and Local Activism among Rural Women in Nepal”. Unpublished PhD. Dissertation, Harvard University.

Sharma, S. (2004). Aid policies, practices and impact. In S. Sharma, J. Koponen \& D. Gyawali (Eds.), Aid under stress: water, forest and Finnish support in Nepal (pp.80-114). Kathmandu: Himal Books.

Shrestha, N. R. (1999). In the name of the development: A reflection on Nepal. Kathmandu: Educational Enterprise.

Subedi, M. S. (2005) Foreign aid, sustainable development and Rapti IRDP. Occasional Papers in Sociology and Anthropology, 9, 231-57.

Tarnowski, C. B. (2002). "Forest Places, Political Spaces: The Social Implications of Community Forestry in Nepal”. Unpublished Master Degree Thesis, University of Georgia.

Thompson, B. and Pertschuk (1992). Organizing communities for risk factor change. In J. K. Ockene (Eds.), Prevention of coronary heart diseases (pp. 493-515). Little-Brown: MA.

UNDP (2004). Nepal human development report 2004: Empowerment and poverty reduction, Kathmandu: UNDP.

Uphoff, N. (1986). Improving international irrigation management with farmer participation: Getting the process right. Boulder, Colo: Westview Press.

Uphoff, N. (1996). Learning from Gal Oya: Possibilities for participatory development and post-Newtonian social science. London: IT Publications.

Upreti, L. (2007). Role of cognitive social captial in sustainable irrigation management: Some observations from Western Tarai, Nepal. Contributions to Nepalese Studies, 34, (2), 183219.

Villarreal, M. (2002). The voices and representation of the poor: Striving for government aid in Western Mexico. In $\mathrm{N}$.
Webster and L. Engberg- Pederson (Eds.), In the name of the poor: Contesting political space for poverty reduction (PP.78103). London/New York: Zed Books.

Westergaard, K. \& Hossain, A. (2002). Local institutions in Bangladesh: An Analysis of civil society and local election. In N. Webster and L. Engberg- Pedersen (Eds.), In the name of the poor (pp. 208-232). London and New York: Zed Books.

Williams, G., Veron, R., Corbridge, S., \& Srivastava, M. (2003). Participation and power: Poor people's engagement with India's employment assurance scheme in Martin Doornbos. Development and Change, 34 (1), 163-192. 